\title{
Revisiting Chemically Enhanced Primary Treatment of Wastewater: A Review
}

\author{
Wudneh Ayele Shewa * and Martha Dagnew \\ Department of Civil and Environmental Engineering, Western University, 1151 Richmond Street, London, \\ ON N6A 3K7, Canada; mdagnew@uwo.ca \\ * Correspondence: wshewa@uwo.ca
}

Received: 2 July 2020; Accepted: 13 July 2020; Published: 23 July 2020

\begin{abstract}
Chemically enhanced primary treatment (CEPT) is a process that uses coagulant and/or flocculant chemicals to remove suspended solids, organic carbon, and nutrients from wastewater. Although it is not a new technology, it has received much attention in recent years due to its increased treatment capacity and related benefits compared to the conventional primary treatment process. CEPT involves both physical and chemical processes. Alum and iron salts are the commonly used coagulants in CEPT. Several types of anionic, cationic, and uncharged polymers are used as flocculants, where poly aluminum chloride (PACL) and polyacrylamide (PAM) are the widely used ones. Some of the coagulants and flocculants used may have inhibitory and/or toxicity effects on downstream treatment and recovery processes. There has been an increasing amount of work on the treatment of wastewaters from various sources using CEPT. These wastewaters can range from municipal/domestic wastewater, combined sewer overflow, landfill leachate, cattle manure digestate to wastewaters from textile industry, pulp and paper mill, slaughterhouse, milk processing plant, tannery and others. In recent cases, CEPT is employed to enhance carbon redirection for recovery and substantially reduce the organic load to secondary treatment processes. CEPTs can remove between $43.1-95.6 \%$ of COD, $70.0-99.5 \%$ suspended solids, and $40.0-99.3 \%$ of phosphate depending on the characteristics of wastewater treated and type of coagulants and/or flocculants used. This article reviews the application, chemicals used so far, removal efficiencies, challenges, and environmental impacts of CEPT.
\end{abstract}

Keywords: chemically enhanced primary treatment; coagulant; flocculant; removal efficiency; sludge; wastewater

\section{Introduction}

Primary wastewater treatment has been identified as a key area of research in improving the sustainability of wastewater treatment processes [1]. Conventional primary treatment processes' major focus has been suspended solids and phosphorus removal. In chemically enhanced primary treatment (CEPT), the major objective is to remove pollutants such as organic carbon (carbon redirection) and nutrients and concentrate it in the sludge produced, which can be regarded as valuable resources to increase energy recovery. There has been an increasing amount of work on the treatment of wastewaters from various sources using CEPT. These wastewaters can range from municipal/domestic wastewater, combined sewer overflow, landfill leachate, cattle manure digestate to wastewaters from textile industry, pulp and paper mill, slaughterhouse, milk processing plant, tannery and others. There is some evidence suggesting the use of CEPT to treat industrial wastewaters that are difficult to treat. For example, among different physical, chemical, biological, and advanced chemical oxidation technologies, chemical coagulation and flocculation is still a cost-comparative alternative for the treatment of industrial textile wastewaters and is widely practiced by small to large scale industries [2]. 
Furthermore, CEPT provides effective treatment for excess wet weather flows, avoiding high capital investments for full biological treatment, particularly with infrequent storm events [3]. It has been reported that hydraulic capacities of existing primary sedimentation tanks can be increased by a factor of up to three by addition of coagulants/flocculants, which is often sufficient to manage peak wet weather flows [4]. Furthermore, compared to conventional primary clarifiers, a CEPT clarifier can be designed in a smaller size (even up to $50 \%$ ) while treating the same amount of wastewater, which translates to capital cost savings [5].

CEPT consists of adding chemicals (metal salts and/or polymers in the form of organic polyelectrolytes) to increase the coagulation, flocculation, and sedimentation of raw wastewater. The growing global concern with environmental issues has raised the interest in the research into coagulants to reduce the use of metal salts [6]. Several effective coagulants are present in nature, which can be used either directly or after modification [7]. In recent years, CEPT has been used at various wastewater treatment plants for phosphate removal, clarification of wastewater, reduction in sludge volume, and increase in surface overflow rates (SORs) [8]. 'Scopus' search result with keyword "chemically enhanced primary treatment" is shown in Figure 1. It can be seen from Figure 1 that a considerable amount of literature has been published on CEPT, where a gradual increase in the number of publications was observed from 2013, reaching a maximum in 2017. However, a review focusing on the application, challenges, and environmental impact of CEPT is necessary. Therefore, this paper aims to provide an updated overview of CEPT technology.

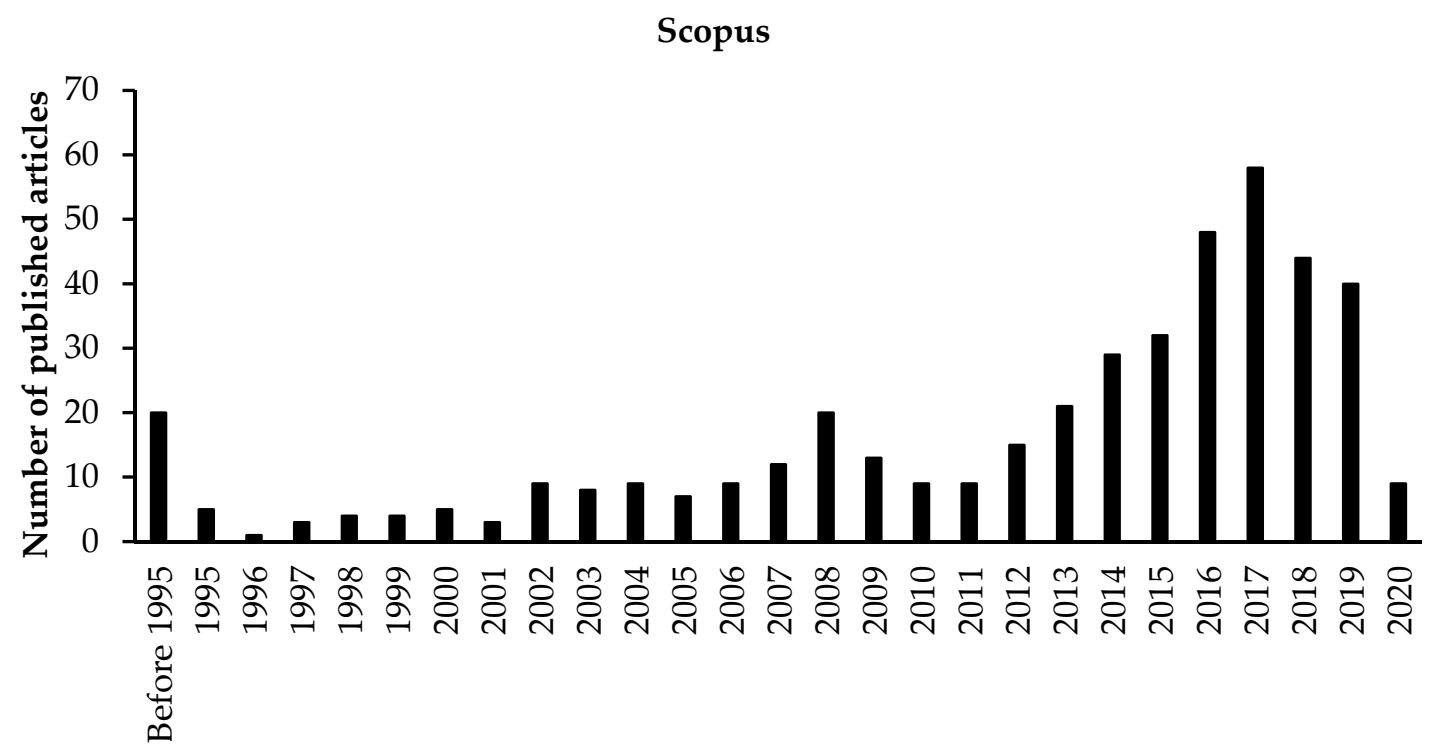

Year

Figure 1. The number of peer-reviewed articles on CEPT published in the last two decades (Source Scopus, March 2020).

\section{Application and Efficiencies of CEPT Processes}

Harleman and Murcott [9] provided CEPT application examples from Mexico City, Southern California, Hong Kong, Sao Paulo, and Rio de Janeiro. For instance, in Hong Kong, over 75\% of sewage ( $\sim 2.2$ million $\mathrm{m}^{3}$ per day) in the catchment area of the Harbor Area Treatment Scheme is treated by the CEPT process [10]. The objective here was to generate effluent that can be directly discharged to the sea. There are also several other case studies of CEPT large scale applications [11-14] where the objective was typically to reduce the load on the downstream process.

The carbon, suspended solids, and nutrient removal efficiencies of CEPT reported in the literature are given in Table 1. Most of these studies were conducted using a bench-scale setup. As can be seen from Table 1, CEPTs can remove between 43.1-95.6\% of COD, 70.0-99.5\% suspended solids, 
and 40.0-99.3\% of phosphate depending on the characteristics of wastewater treated and type of coagulants and/or flocculants used. In some of the cases where very high COD removals were reported, due to the increased redirection of carbon to the CEPT sludge, the carbon going to the subsequent secondary treatment processes may be low, and the CEPT effluent may not meet the requirement for denitrification process that is required for nitrogen removal. As far as nutrient removal is concerned, despite phosphorus removal, the removal of nitrogen using CEPT is limited. Therefore, CEPT is often combined with other processes (such as shortcut nitrification-denitrification, ion exchange) if removal of nitrogen is required [12,15-17].

Dolejs et al. [18] considered two process schemes to achieve energy neutrality or reduce energy consumption using CEPT in wastewater treatment facilities. First, a two-stage biological process, i.e., a high-rate primary treatment for COD capture (generally named A-stage) and biological nutrient removal systems as secondary treatment (B-stage). Second, innovative biological nitrogen removal schemes based on shortcut nitrogen removal via nitritation/denitritation or partial nitrification with an anammox process. Wan et al. [15] reported that the A-B processes that include CEPT are the most feasible options to improve energy recovery and minimize in-plant energy consumption. The COD flow and biogas production potential in typical conventional activated sludge process and A-B process with CEPT as A-stage and shortcut nitrification and denitrification as B-stage is shown in Figure 2. In addition to the nitrogen removal in the A-B process, notice the COD mass flow to the CHP (combined heat and power plant) (Figure 2a,b) indicate $33 \%$ of influent COD ultimately converted to biomethane in the conventional process compared to $43 \%$ for the A-B process. 


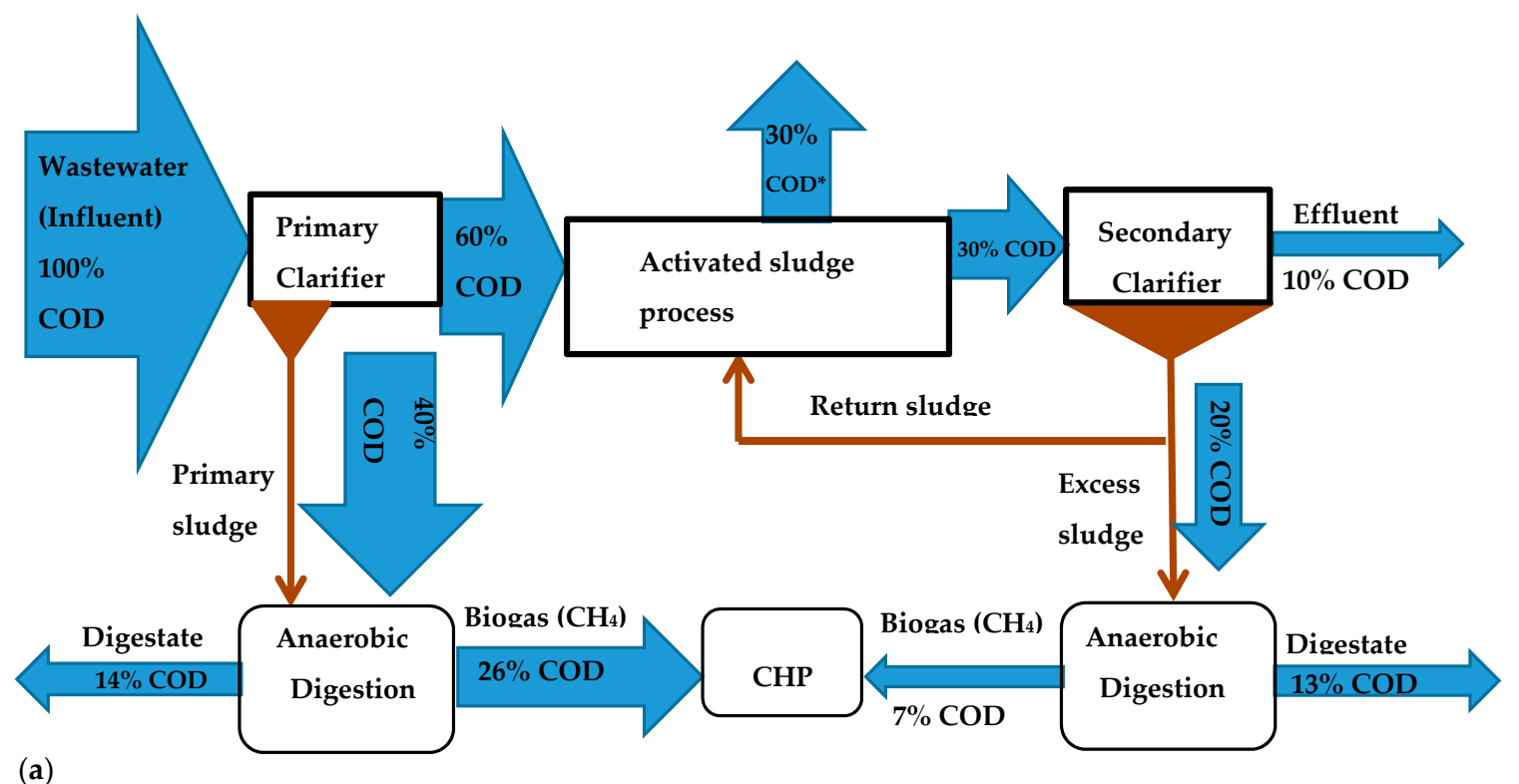

(a)

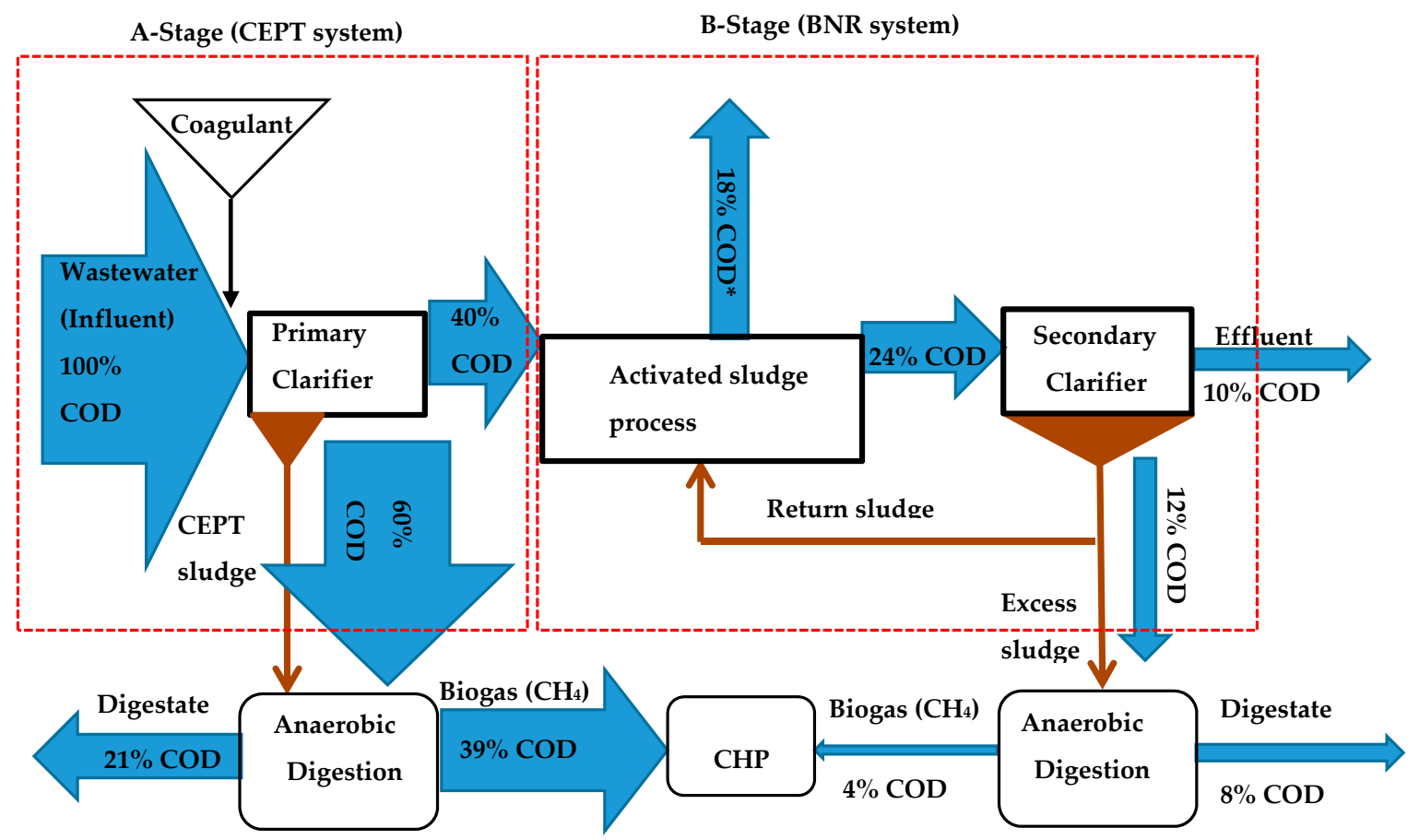

(b)

Figure 2. COD mass flow through (a) Conventional municipal wastewater treatment plant and; (b) A-B process with CEPT as A-stage and shortcut nitrification and denitrification as B-stage (Reproduced with permission [15]). (CEPT: Chemically enhanced primary treatment; BNR: Biological nitrogen removal; CHP: Combined heat and power plant COD*: COD transferred to the electron acceptor (oxygen)). 
Table 1. Removal efficiencies of selected CEPT processes.

\begin{tabular}{|c|c|c|c|c|c|c|c|c|}
\hline \multirow{2}{*}{ Wastewater Source } & \multicolumn{2}{|l|}{ Coagulant } & \multicolumn{2}{|c|}{ Flocculants } & \multicolumn{3}{|c|}{ Removal Efficiency (\%) } & \multirow[t]{2}{*}{ Reference } \\
\hline & Name & Dosage $(\mathrm{mg} / \mathrm{L})$ & Name/Type & Dosage (mg/L) & COD & Suspended Solids & Phosphate & \\
\hline Municipal & PACI & 100 & - & - & 68.8 & NA & 76 & [12] \\
\hline Municipal & Ferric chloride & $20-30$ & Anionic polymer & $0.2-1.5$ & $48-55$ & 74-84 & NA & [19] \\
\hline Municipal & Ferric chloride & 30 & $\begin{array}{l}\text { Anionic polymer } \\
\text { (Magnafloc 1011) }\end{array}$ & 0.5 & $\mathrm{NA}$ & 80 & $40^{c}$ & [20] \\
\hline Municipal & Ferric chloride & 50 & Anionic polymer & 10 & 73 & 85 & 80 & [21] \\
\hline Municipal & Moringa oleifera & 100 & Alum & 10 & 64 & NA & NA & [22] \\
\hline Municipal & Ferric chloride & 40 & Anionic polymer & 0.5 & NA & 83 & NA & [23] \\
\hline Municipal & Cement kiln dust & 50 & PAM & 0.2 & 85 & NA & 95 & [24] \\
\hline Municipal & Polyaluminium ferric chloride & 25 & - & - & & $>90$ & - & [11] \\
\hline Municipal & Fly ash based solution & $3.2 \mathrm{~mL} / \mathrm{L}$ & - & - & 65 & 92 & 98 & [24] \\
\hline Municipal & $\mathrm{PACl}$ & 16 & & & 83 & NA & 97 & [25] \\
\hline Municipal & Ferric chloride & 15 & $\mathrm{PACl}$ & 0.5 & 76 & 89 & 84 & [26] \\
\hline Municipal & Ferrric chloride & 30 & - & - & $63^{\mathrm{e}}$ & NA & 97.3 & [27] \\
\hline Municipal & Ferric chloride & 40 & - & - & 62 & 90 & 77 & [28] \\
\hline Municipal & Ferric chloride & $20^{\mathrm{e}}$ & - & - & $75.6^{\mathrm{a}}$ & NA & 99.3 & [29] \\
\hline Landfill leachate & Ferric chloride & 2000 & - & - & 80 & NA & NA & [30] \\
\hline Landfill leachate & $\mathrm{PACl}$ & 2000 & - & - & 43.1 & 92.2 & NA & [31] \\
\hline Landfill leachate & Alum & 9500 & - & - & 62.8 & 90.1 & NA & [31] \\
\hline Landfill leachate & $\mathrm{PACl}$ & 7.2 & Psyllium husk & 0.4 & 64 & 96 & NA & [32] \\
\hline Landfill leachate & guar gum & 44.4 & - & - & 22.6 & NA & NA & [33] \\
\hline Compost leachate. & Salvia hispanica & 40 & - & - & 39.8 & $62.4^{\mathrm{b}}$ & NA & [34] \\
\hline Milk Processing Plant & Chitosan & 25 & - & - & 54 & $94.3^{\mathrm{b}}$ & NA & [35] \\
\hline Chitin production & chitosan & 86.4 & - & - & 59 & 98 & 90 & [36] \\
\hline Chitin production & PACL & 17.6 & - & - & 50 & 97 & 91 & [36] \\
\hline Chitin production & PAM & 79.3 & - & - & 46 & 99 & 92 & [36] \\
\hline Beverage industry & Ferric chloride & 300 & - & - & 73 & 97 & 95 & [37] \\
\hline Beverage industry & Ferric chloride & 100 & PAM & 25 & 91 & 97 & 99 & [37] \\
\hline Pulp and paper mill & Alum & 500 & C-PAM (Organopol 5415) & $1-6$ & 95.6 & 99.5 & NA & [38] \\
\hline Pulp mill & Aluminum chloride & 871 & starch-g-PAM g-PDMC & 22.3 & NA & $95.7^{\mathrm{b}}$ & NA & [39] \\
\hline Tannery & Alum & $200-240$ & - & - & $53.3-60.9$ & $94.3-97.1$ & NA & [13] \\
\hline Textile effluent & Chitosan & 18 & - & - & 70.9 & 98.36 & NA & [40] \\
\hline Oil Refinery & Alum & 40 & - & - & 51.7 & 85.3 & NA & [41] \\
\hline Oil Refinery & Moringa oleifera & 70 & - & - & 38.6 & 62.1 & NA & [41] \\
\hline Palm oil mill & Alum & 13,000 & - & - & 52.4 & 84.9 & NA & [42] \\
\hline Palm oil mill & Rice husk ash & 12,000 & - & - & 52.4 & 83.8 & NA & [42] \\
\hline Cattle manure digestate & Ferric chloride & 40 & Anionic PAM & 0.2 & 75 & NA & 97 & [43] \\
\hline Synthetic wastewater & Alum recovered from sludge & 12 & - & - & 53 & $96^{\mathrm{b}}$ & 94 & [44] \\
\hline Mixture of wastewater ${ }^{d}$ & Ferric chloride & 10,000 & Lime & 4000 & 75 & 70 & NA & [45] \\
\hline
\end{tabular}

a Total organic carbon (TOC) removal (\%); ${ }^{\mathrm{b}}$ Turbidity removal (\%); ${ }^{\mathrm{c}}$ Total phosphorus removal (\%); ${ }^{\mathrm{d}}$ Mixture of waste coming from 525 small-scale industries manufacturing textile and dyestuff intermediates, pigments and pharmaceuticals; ${ }^{e} \mathrm{mg} \mathrm{Fe} / \mathrm{L}_{\text {sewage; }}$ PAM: Polyacrylamide; PACl: Poly aluminum chloride; PDMC: poly (2-methacryloyloxyethyl) trimethylammonium chloride; NA: Not available. 
CEPT can increase the dissolved heavy metal removal efficiencies of chromium, copper, nickel, and zinc from raw wastewater, preventing heavy metals from reaching downstream processes and the receiving waters [23]. It should be noted that the increased metal precipitation and accumulation in the CEPT sludge could potentially affect the subsequent sludge treatment and reuse processes. Therefore, disposal of CEPT sludge rich in harmful metals should be done carefully to avoid the adverse impact on the environment. CEPT is also an excellent option to remove dyes from wastewater. Riera-Torres et al. [46] demonstrated that a combination of membrane filtration and CEPT could provide almost $100 \%$ of dye removal. CEPT is also one of the most commonly used methods in tannery wastewater treatment [47]. Micropollutants can also be removed by CEPT [48-50]. A study conducted by Zhou et al. [50] showed that $65 \%$ of retinoids and $73 \%$ of endocrine-disrupting chemicals (EDCs) were removed from municipal wastewater after aluminum (Al)-based CEPT. In comparison, $80 \%$ of retinoids and $72 \%$ of EDCs were removed after iron (Fe) based CEPT. A medium-low removal efficiency (38-55\%) of hydrophobic organic micropollutants (OMPs) was reported by Taboada-Santos et al. [51], where the removal is attributed to the sorbed fraction of the OMPs into total suspended solids and flocs formed.

\section{Mechanisms of Coagulation and Flocculation}

Coagulation and flocculation are the processes involved in CEPT. Coagulation refers to the process where particles are destabilized, and the aggregates (coagula) tend to be small and dense, whereas flocculation referrers to the process where aggregates (flocs) tend to be larger and more open in structure [52]. The main mechanisms in coagulation can be classified into (1) double layer compression, (2) adsorption and charge neutralization (3) entrapment of particles in the precipitate, and (4) interparticle bridging. These mechanisms are described in Table 2 [1,53-56]. The classical method of colloid destabilization is double-layer compression [56]. For the case where a polymer and the adsorption site are of opposite signs, it is postulated that charge neutralization is the dominant mechanism. Chemical sorption and accumulation in the CEPT sludge is the mechanism for the removals of micropollutants [50]. The mechanisms of flocculation are (1) micro-flocculation (also known as perikinetic flocculation) in which particle aggregation is brought about by the random thermal motion of fluid molecules known as Brownian motion or movement and (2) macro-flocculation (also known as orthokinetic flocculation) in which particle aggregation is brought about by induced velocity gradients and differential settling [1].

Table 2. Mechanisms of coagulation.

\begin{tabular}{|c|c|}
\hline Mechanism & Description \\
\hline $\begin{array}{l}\text { Double-layer } \\
\text { compression }\end{array}$ & $\begin{array}{l}\text { The zeta potential represents the net charge of colloidal particles. Consequently, the higher the value of the } \\
\text { zeta potential, the greater is the magnitude of the repulsive power between the particles and hence the more } \\
\text { stable is the colloidal system. Coagulation increases the ionic strength of the wastewater, which has the effect } \\
\text { of compressing the electrical double layer (EDL), which in turn reduces the zeta potential. If this layer is } \\
\text { sufficiently compressed, then the van der Waals force will be predominant across the entire area of influence, } \\
\text { so that the net force will be attractive and no energy barriers will exist. The net repulsive energy would } \\
\text { become smaller or even would be eliminated, allowing the particles to approach each other and agglomerate } \\
\text { (Figure S1). }\end{array}$ \\
\hline $\begin{array}{l}\text { Adsorption and charge } \\
\text { neutralization }\end{array}$ & $\begin{array}{l}\left.\text { The aqua metallic ions }\left(\mathrm{Al}\left(\mathrm{H}_{2} \mathrm{O}\right)_{6}{ }^{3+} \text { or } \mathrm{Fe}\left(\mathrm{H}_{2} \mathrm{O}\right)_{6}{ }^{3+}\right)\right) \text { formed during coagulation become part of the ionic } \\
\text { cloud surrounding the colloid and, because they have a great affinity for surfaces, are adsorbed onto the } \\
\text { surface of the colloid where they neutralize the surface charge. Once the surface charge has been neutralized, } \\
\text { the ionic cloud dissipates, and the electrostatic potential disappears so that contact occurs freely. }\end{array}$ \\
\hline $\begin{array}{l}\text { Entrapment of particles in } \\
\text { the precipitate (sweep } \\
\text { coagulation) }\end{array}$ & $\begin{array}{l}\text { When the coagulants alum }\left[\mathrm{Al}_{2}\left(\mathrm{SO}_{4}\right)_{3}\right] \text { or ferric chloride }\left(\mathrm{FeCl}_{3}\right) \text { are added in high enough concentration, } \\
\text { they will react with hydroxides }\left(\mathrm{OH}^{-}\right) \text {to form metal hydroxide precipitates, } \mathrm{Al}(\mathrm{OH})_{3(\mathrm{~s})} \text { or } \mathrm{Fe}(\mathrm{OH})_{3(\mathrm{~s}) \text {, }} \\
\text { respectively. The colloidal particles become entrapped in the precipitates either during the precipitate } \\
\text { formation or just after. }\end{array}$ \\
\hline Interparticle bridging & $\begin{array}{l}\text { Bridging occurs when segments of a high-molecular-weight polymer adsorb on more than one particle, } \\
\text { thereby linking the particles together. When a polymer molecule comes into contact with a colloidal particle, } \\
\text { some of the reactive groups on the polymer adsorb on the particle surface and other portions extend into the } \\
\text { solution. If a second particle with an open surface can adsorb the extended molecule, then the polymer will } \\
\text { have formed an interparticle bridge. }\end{array}$ \\
\hline
\end{tabular}




\section{Coagulants Used in CEPT}

\subsection{Synthetic Coagulants}

The commonly used synthetic coagulants fall into two general categories: those based on aluminum and those based on iron. Aluminum-based coagulants include aluminum sulfate (alum), aluminum chloride, sodium aluminate, aluminum chlorohydrate, and sodium aluminate. Iron coagulants include ferric sulfate, ferrous sulfate, chlorinated copperas, ferric chloride, polysilicate-iron (PSI). Alternative coagulants based on pre-hydrolyzed forms of aluminum (such as poly aluminum chloride (PACl)) and iron (poly ferric sulfate (PFS)) are more effective than the traditional additives [57]. The popularity of aluminum and iron coagulants arises not only from their effectiveness as coagulants but also from their ready availability and relatively low cost. The efficacy of these coagulants arises principally from their ability to form multi-charged poly-nuclear complexes in solution with enhanced adsorption characteristics [3]. Other chemicals used as coagulants include hydrated lime and magnesium carbonate. Moreover, Ecofloc CP [58], cement kiln dust [24], and fly ash-based coagulants [59] were also found successful for municipal wastewater CEPT applications. Due to their superior color removal even at small dosage and affectivity at wider $\mathrm{pH}$ range $\mathrm{PACL}, \mathrm{PFS}$, poly aluminum ferric chloride (PAFCl), and poly ferric chloride $(\mathrm{PFCl})$ may be considered as better coagulants for the treatment of industrial textile wastewaters of wastewater [2].

\subsection{Recycled Chemical Sludge}

Some studies investigated methods of recovering coagulants from water treatment and CEPT sludges and use it for CEPT, which will probably make the CEPT process more cost-effective. There are different methods of coagulant recovery from water treatment residuals that include acidification, basification, ion exchanging, and membranes [44]. For example, in the acidification method, alum and iron salts may be recovered from sludge by adding sulfuric acid (Equation (1)).

$$
\operatorname{Metal}(\mathrm{OH})_{x}+x \mathrm{H}^{+}+\frac{x}{2} \mathrm{SO}_{4}^{2-} \rightarrow \operatorname{Metal}\left(\mathrm{SO}_{4}\right)_{x / 2}+x \mathrm{H}_{2} \mathrm{O}
$$

where, Metal represents aluminum or iron.

Recycling coagulants has both advantages and limitations. Xu et al. [60] have shown that the quality of treated wastewater by recovered and fresh coagulant is similar, and the effect of recovered coagulant might be better than that of fresh coagulants in some respects, such as turbidity removal. A similar study conducted by $\mathrm{Xu}$ et al. [44] verified the possibility of ferric coagulant recovery using acidification from CEPT sludge and its recycled product in CEPT to make the process more cost-effective, as well as reduce sludge volume. Chakraborty et al. [28] studied the reusability of recovered iron coagulant from primary municipal sludge. They showed that an annual saving in operating costs of a 1 MGD plant of USD 5052 could be achieved. A similar study conducted by Taheriyoun et al. [61] investigated the feasibility of chemical sludge as a coagulant aid in the coagulation-flocculation process of steel mill wastewater treatment. This study revealed that the use of CEPT sludge could reduce up to $60 \%$ of the coagulant and flocculent dose without adversely affecting the final turbidity. Considering the economic benefits due to chemical savings, the use of recovered coagulants is recommended. However, coagulant recovery is at its early stage of research, and cost-benefit analysis needs to be done to ensure sustainability and its application at a larger-scale. It should also be noted that in coagulant recovery processes such as acidification or basification, other metals may be solubilized along with the coagulant metal, and reuse of the recovered coagulant will recycle metals that should again be precipitated along with the coagulant [55].

As explained above, using recovered coagulants from sludge is one option to reduce the cost involved in chemicals added for CEPT and promote sustainability. The other option is using recovered iron or alum salts from wastes from some industrial processes. For example, titanium oxide $\left(\mathrm{TiO}_{2}\right)$ production plants generate a large amount of iron as iron sulfate or chloride salt as a waste. Based on 
global $\mathrm{TiO}_{2}$ production data from 2007, around 1.3 million tonnes or $40 \%$ of the total iron contained in $\mathrm{TiO}_{2}$ mineral resources is not recovered but is lost as waste [62]. Therefore, an innovative technology could be adopted to recover this iron and use it for CEPT, which would, in turn, maximize waste recovery.

\subsection{Natural Coagulants}

Natural coagulants are non-toxic, biodegradable, environment friendly, and have the ability to encapsulate [2]. Natural coagulants will not hinder biological treatment (if required) and may act as nutrients for the microorganisms. Moreover, organic coagulants, as opposed to inorganic ones, do not cause a significant increase in chloride and sulfate ion concentrations, which facilitates the use of treated wastewater in the water reuse systems, such as irrigation of crops [63]. Czerwionka et al. [63] studied the impact of organic coagulants on the efficiency of nutrient removal processes and verified that the organic coagulants did not have a significant impact on the values of unit processes rates associated with the biological removal of nitrogen and phosphorus in the activated sludge process. The organic coagulants used in this study are Cofloc, C29510, and Sedifloc 575 [63]. In another study, Luo et al. [64] assessed and verified the capability of CEPT for the treatment of printing and dyeing wastewater (PDW) using three different coagulants (ferrous sulfate, aluminum sulfate, and polymeric iron sulfate). One of the novel findings of this study is that the microbial community of PDW from the industrial park after CEPT was similar to the raw wastewater. Moreover, natural coagulants do not induce a change in the physicochemical properties of treated water [7].

Natural coagulants could be plant-based, animal-based, or made from microbes. Plant-based coagulants (especially, Moringa oleifera) have shown significant promise in treating the wastewater emanating from different types of industries [65]. Cheng et al. [33] investigated the feasibility of guar gam for sustainable landfill leachate treatment and reported that $22.6 \%$ of COD removal could be achieved at guar gum dosage of $44.4 \mathrm{mg} / \mathrm{L}$. The removal of COD efficiency reported by Cheng et al. [33] is less than studies conducted using synthetic/inorganic coagulants for leachate treatment. For example, Ghafari et al. [31] reported $62.8 \%$ and $43.1 \%$. COD removal was using Alum (dosage $=2000 \mathrm{mg} / \mathrm{L}$ ) and $\mathrm{PACl}($ dosage $=9500 \mathrm{mg} / \mathrm{L})$, respectively (Table 1$)$. The reason for the lower removal efficiency of the natural coagulant could be attributed to the lower dosage of the coagulant. To obtain an equivalent COD removal efficiency as conventional coagulants (inorganic coagulants), a larger dose of natural coagulants is required due to its weaker coagulation capability [66].

\subsection{Coagulant Selection Procedure}

Although there are many types of coagulants depicted above, the most effective coagulant for particular wastewater still largely depends on the outcome of laboratory jar testing [31] and the optimization of each plant is required to give maximum efficiency in the selection of both chemical and dose [67]. Feo et al. [58] defined a simple multi-criteria procedure to select the best coagulant as well as the relative dose based on the adoption of the following five criteria: COD percentage removal, sludge volume after two hours, coagulant dose, coagulant cost and $\mathrm{pH}$ percentage variation. The multi-criteria procedure defined by Feo et al. [58] can be summarized in the following six steps (considering five criteria for evaluation):

1. Construct a complete alternatives matrix (CAM), composed of five columns (the criteria) and as many rows as the number of alternatives.

2. Eliminate from the CAM the rows relating to the alternatives with a COD percentage removal less than $40 \%$, thus obtaining a simplified alternative matrix (SAM).

3. Normalize the SAM. The normalization is obtained by dividing each value in the first column by the maximum value of the same column and then dividing the minimum value in the other columns by the considered value.

4. The fourth step is to attribute a weight to each criterion, distributing the value 10 among the 5 criteria adopted. An "equilibrate" weight distribution is obtained by multiplying each value by 
2. This corresponds to giving a $20 \%$ relevance to each criterion in the choice of the best coagulant and dose.

5. Calculate for each alternative an average index (AI) obtained by taking the average of the 5 weighted values for each alternative.

6. List the alternatives in decreasing order in terms of AI. The first coagulant and the relative dose will be the best choice.

Based on the procedure described by Feo et al. [58], Dong et al. [26] used equilibrate weight distribution and therefore assigned an equal weight of 2 to each criterion (removals of tCOD, sCOD, TP, and TSS), and determined the corresponding index for each polymer and its impact on each parameter. Averages of the four weighted values were then compared (Tables S1 and S2), and the polymer with the highest index (PACL) was selected as the optimal polymer.

Although the cost of the coagulants is one of the five criteria defined by Feo et al. [58], the procedure illustrated by Dong et al. [26] did not include cost, which needs to be included as one criterion. The cost of chemicals used in CEPT should be given due consideration when comparing coagulants. The cost of commonly used coagulants and flocculants are depicted in Table 3. A similar procedure could be adopted for the selection of the coagulant. Furthermore, modeling of the CEPT process is required to evaluate the performance of the process in large-scale applications. Since influent quality is affected by several site-specific conditions, the preliminary collection of site-specific data for COD fractionation is always beneficial [68]. Moreover, the overall cost-effectiveness and environmental impact of coagulants should be considered in the evaluation of coagulants. It should also be noted that the addition of chemical costs will increase the capital and operating costs of wastewater treatment. However, the cost associated with chemical addition could be compensated by the benefit of CEPT that includes energy recovery from the CEPT sludge and a reduction in the aeration energy required for secondary treatment due to the increased removal of carbon. Diamantis [69] studied the cost and benefits of CEPT under controlled laboratory conditions and produced a conceptual design for a community of 2000 inhabitant equivalents. According to Diamantis [69], the capital and operational costs of CEPT were 0.11 and $0.09 \mathrm{EUR} / \mathrm{m}^{3}$, respectively, and the biogas generated is used for digester heating and the overall process is energy self-sufficient.

Table 3. Cost of commonly used coagulants and flocculants in CEPT.

\begin{tabular}{cccc}
\hline Chemicals & Unit Cost (EUR/ton) & Average Dose $(\mathbf{m g} / \mathrm{L})$ & Cost $\left(\mathrm{EUR} / \mathbf{m}^{\mathbf{3}}\right)$ \\
\hline Alum & $175-200$ & $15-45$ & $0.003-0.010$ \\
Ferric chloride & $250-350$ & $30-60$ & $0.007-0.021$ \\
Ferric sulfate & $250-350$ & $30-60$ & $0.007-0.021$ \\
PACL & $250-400$ & $15-40$ & $0.004-0.016$ \\
Cationic Polymer & $2200-3080$ & $0.1-2.0$ & $0.001-0.006$ \\
Anionic polymer & $2000-2300$ & $0.5-3.0$ & $0.001-0.007$ \\
\hline
\end{tabular}

Source: Lema and Suarez [70].

\section{Flocculants Used in CEPT}

Flocculants used in CEPT are mainly synthetic polymers that can be classified into three types, depending on their charge as cationic (positively charged), anionic (negatively charged) and nonionic (uncharged). There are also naturally occurring flocculants (starch derivatives, guar gums, tannins, alginates, etc.). When the polymer is used in combination with a conventional coagulant, the aim is to not only achieve better floc characteristics in terms of size, strength, settleability and filterability but also earn considerable savings on coagulant dose for the same removal performance [71]. Examples of polymers, which are commonly used in CEPT, are listed in Table 4. These polymers have different chemical structures, vast ranges of molecular weight, and significant differences in charge density. For nonionic polymers, the attraction between particles is entirely the result of the "bridging" effect. However, for cationic and anionic polymers, there is also the possibility that charge neutralization 
can play a role. Both of these effects may operate simultaneously [55]. Among the polymers listed in Table 4, PACl and PAM are widely used in CEPT. Dong et al. [26] compared the removal efficiencies of seven different cationic, anionic and nonionic flocculants and found that $\mathrm{PACl}$ is the best performing flocculant for municipal wastewater.

Table 4. Polymers used in water and wastewater treatment.

\begin{tabular}{|c|c|}
\hline Polymer Type & Examples \\
\hline Cationic & $\begin{array}{ll}\text { - } & \text { Poly(diallyldimethyl ammonium chloride) } \\
\text { - } & \text { Epichlorohydrin/dimethylamine polymers } \\
\text { - } & \text { Cationic polyacrylamides } \\
\text { - } & \text { Poly(alkylamines) [poly(ethyleneimine), poly(vinylamine)] } \\
\text { - } & \text { Poly(styrene) derivatives } \\
\text { - } & \text { Ionenes } \\
\text { - } & \text { Sulphonium polymers } \\
\text { - } & \text { Natural cationic polymers (chitosan, cationic starches) }\end{array}$ \\
\hline Anionic & $\begin{array}{ll}\text { - } & \text { Anionic polyacrylamides } \\
\text { - } & \text { Carboxylic acid polymers } \\
\text { - } & \text { Phosphonic acid polymers } \\
\text { - } & \text { Sulphonic acid polymers } \\
\text { - } & \text { Natural anionic polymers (sulphated polysaccharides, modified lignin sulphonates) }\end{array}$ \\
\hline Nonionic & $\begin{array}{l}\text { - } \quad \text { Polyacrylamide (PAM) } \\
\text { - } \quad \text { Natural non-ionic polymers (starch, cellulose derivatives) }\end{array}$ \\
\hline
\end{tabular}

Source: Renault et al. [57].

Using natural polymers as flocculants is a preferable option for CEPT. In general, the advantages of natural polymers are that they are virtually toxic-free, biodegradable in the environment and the raw products are often locally available, whereas industrialized coagulants may not be [3]. Another alternative is the use of biological flocculants (biopolymers/bioflocculants) derived from bacteria and fungi, which could be environmentally friendly [72]. Numerous works have demonstrated that chitosan and its derivatives (in particular grafted biopolymers) can be a potential substitute for metallic salts and synthetic polyelectrolytes in the treatment of wastewater for the removal of both particulate and dissolved substances $[40,57,73]$. Therefore, chitosan is one of the most promising natural flocculants. Moreover, chitosan can form complexes with metallic ions [74]. Some studies explored the combined application of natural and synthetic chemicals in CEPT. Bhuptawat et al. [22] studied the use of a natural coagulant (water extract of Moringa oleifera seed) in combination with alum $\left(\mathrm{Al}_{2}\left(\mathrm{SO}_{4}\right)_{3} \cdot 18 \mathrm{H}_{2} \mathrm{O}\right)$ for municipal wastewater treatment. According to this study, with the coagulant combination of $100 \mathrm{mg} / \mathrm{L}$ of $M$. oleifera with $10 \mathrm{mg} / \mathrm{L}$ alum, a maximum overall removal of $64 \%$ of COD was achieved (Table 1).

\section{Impact of CEPT on Different Wastewater Fractions}

Wastewater characteristics and corresponding fractions vary from place to place. For example, Pasztor et al. [75] collected and summarized the data of wastewater COD fractions from several countries and reported that the ratio of COD components in raw wastewater is very different. The average composition is as follows: Inert particulate $=17.1 \%$, slowly biodegradable $=57.9 \%$, inert soluble $=$ $7.8 \%$ and readily biodegradable $=17.5 \%$ [75]. In addition to particulate COD and P fractions, CEPT can remove colloidal fractions (soluble and slowly degradable) of wastewater. The colloidal particles found in wastewater typically have a net negative surface charge. The size of colloids (about 0.001 to $1 \mathrm{~mm}$ ) is such that the attractive body forces between particles are considerably less than the repelling forces 
of the electrical charge [1]. Under these stable conditions, Brownian motion (i.e., random movement) keeps the particles in suspension. The coagulation process in CEPT, as previously described in Table 2, destabilizes the colloidal particles so that particle growth can occur as a result of particle collisions and finally settle.

To better understand the impact of CEPT on removal efficiency assessment of different COD and $\mathrm{P}$ components is crucial. Although extensive research has been carried out on CEPT in both bench- and full-scale operations, no single study exists which adequately covers the impact of CEPT on different $\mathrm{COD}$ and $\mathrm{P}$ fractions. We evaluated the CEPT process considering the different COD and phosphorus fractions and indicated the fractions that can potentially be removed from wastewater (Figures 3 and 4). Procedures and methods described by the Water Environment Research Foundation (WERF) [76] and standard methods for the examination of water and wastewater [77] can be used for determining the COD and $\mathrm{P}$ fractions, respectively.

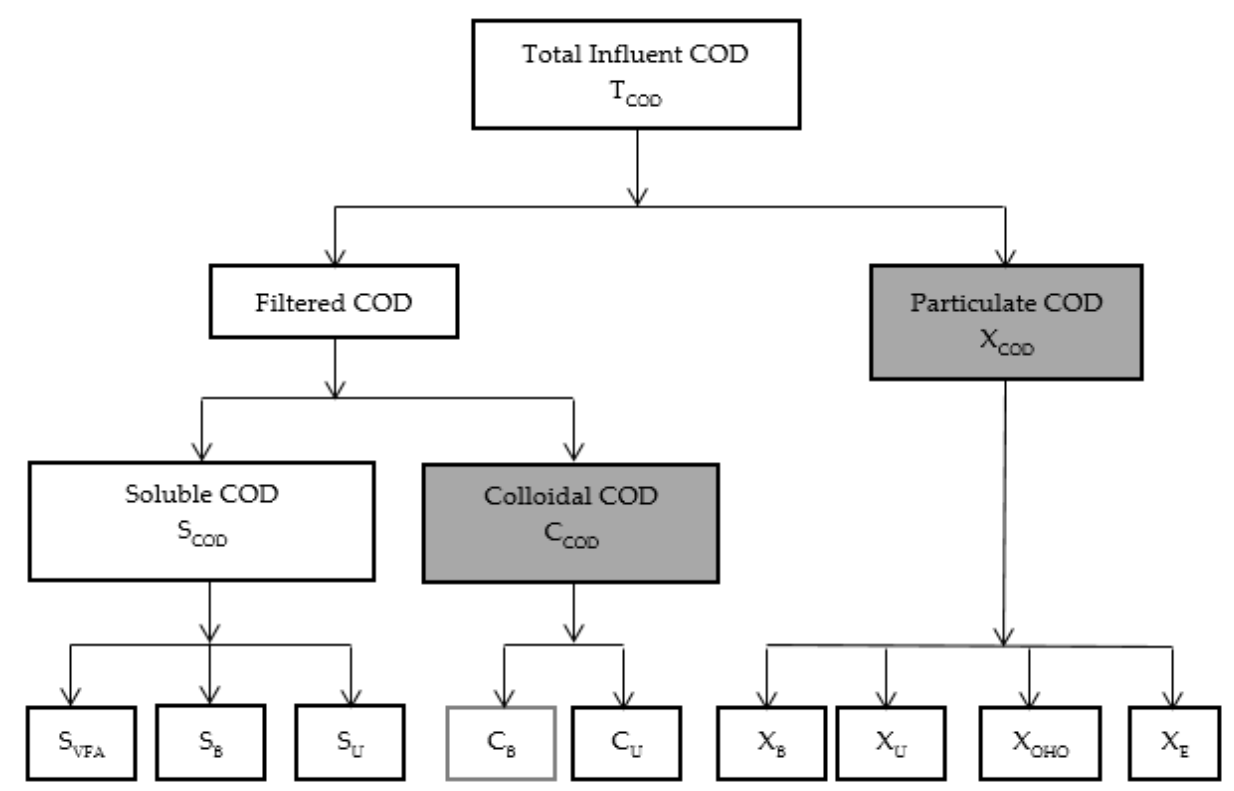

Figure 3. Different fractions of COD in influent wastewater (Adapted from Dynamita SALR [78]). $\mathrm{S}=$ soluble; $\mathrm{C}=$ colloidal; $\mathrm{X}=$ particulate; $\mathrm{VFA}=$ volatile fatty acid; $\mathrm{B}=$ biodegradable; $\mathrm{U}=$ unbiodegradable; $\mathrm{OHO}=$ ordinary heterotrophs; $\mathrm{E}=$ endogenous decay products; Shaded boxes indicate fractions that can be removed by CEPT.

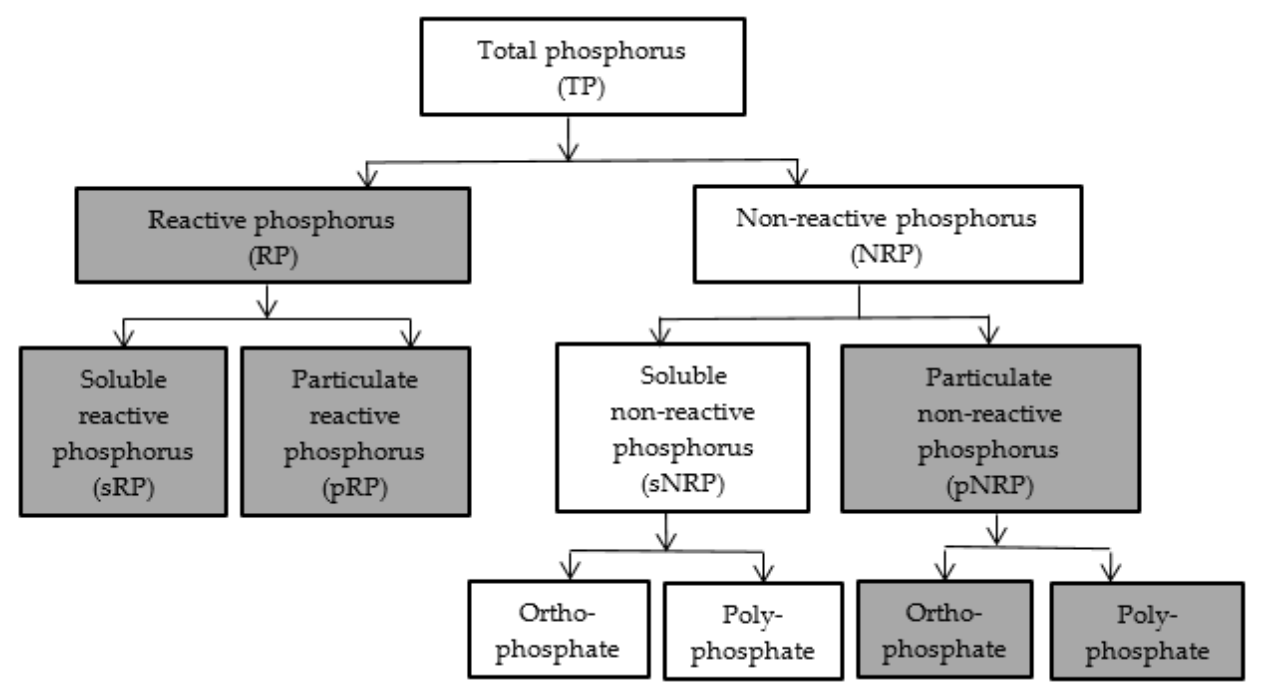

Figure 4. Different fractions of phosphorus in influent wastewater (Adapted from Venkiteshwaran et al. [79]). Shaded boxes indicate fractions that can be removed by CEPT. 
Colloidal COD for conventional primary effluent wastewaters ranges from 29 to $36 \%$ of the total COD [80]. In CEPT, due to the coagulation and flocculation process, the colloidal fraction is significantly removed, resulting in very low to no colloidal COD in the effluent. It should be noted that a well-operated CEPT is capable of almost completely removing colloidal matter [81]. Therefore, assuming a typical total COD concentration of conventional primary effluent $(290 \mathrm{mg} / \mathrm{L})$ and considering only the colloidal COD removal that can be achieved by CEPT, the total COD concentration in the CEPT effluent could range from 186 to $206 \mathrm{mg} / \mathrm{L}$.

\section{CEPT Sludge Treatment, Recovery, and Disposal}

The sludge production in CEPT is higher than the sludge produced from conventional primary treatment due to the chemicals added. The amount of sludge produced by CEPT can be estimated by Equation (2) [82]. The energy production from a CEPT sludge in an anaerobic process can be calculated from a simple mathematical correlation (Equation (3)) as a function of the process efficiency $(\eta A D)$ and the sludge concentration fed into the anaerobic digestor [83]. Equation (2) was derived by considering typical values from a municipal WWTP and a calorific value of $11 \mathrm{~kW} \mathrm{~h} / \mathrm{N} \mathrm{m}^{3} \mathrm{CH}_{4}$ for methane. It should be noted that the energy production might be affected by the increase in inorganic precipitates in the sludge, which could lower the efficiency of biogas production [1].

$$
S P=S S_{\text {in }}-S S_{\text {out }}+K_{\text {prec }} * D
$$

where

$S P=$ sludge production $\left(\mathrm{g} \mathrm{SS} / \mathrm{m}^{3}\right)$

$S S_{i n}=$ suspended solids concentration in influent $\left(\mathrm{g} \mathrm{SS} / \mathrm{m}^{3}\right)$

$S S_{\text {out }}=$ suspended solids concentration in effluent $\left(\mathrm{g} \mathrm{SS} / \mathrm{m}^{3}\right)$

$K_{\text {prec }}=$ sludge production coefficient (g SS/g Metal), typically 4-5 for Fe and 6-7 for Al

$D=$ Dossage of coagulant $\left(\mathrm{g} \mathrm{Metal} / \mathrm{m}^{3}\right)$

$$
E=3.77 * c * \eta_{A D}
$$

where

$E=$ Energy production $\left(\mathrm{KW} \mathrm{h} / \mathrm{m}^{3}\right.$ sludge $)$

$c=$ Sludge concentration $\left(\mathrm{Kg}\right.$ solids $\left./ \mathrm{m}^{3}\right)$

$\eta_{A D}=$ Anaerobic digestion efficiency (typically, $40 \%-50 \%$ in full-scale digesters)

The organic carbon in CEPT sludge could be recovered by hydrolysis and acidogenesis, and the VFAs-rich fermentation liquor can be dosed into wastewater to make up the carbon deficit for denitrification [84]. Some studies conducted on CEPT sludge investigated the degradability of CEPT and the production of biogas from CEPT sludge using anaerobic digestion. The organic carbon transferred to CEPT sludge could increase anaerobic digester gas production or promote autogenous combustion in sludge incineration. On the other hand, CEPT sludge, especially using Al-based coagulants, features a rather low biodegradability and treatability due to the agglomeration of solid matters by the coagulant [25]. Some researchers now argue that some polymers used in CEPT have an adverse effect on the quality of CEPT sludge. Lin et al. [85], for example, argues that PACl, which is one of the best coagulants/flocculants for CEPT, has an inhibitory effect on organic hydrolysis of the CEPT sludge. Therefore, further studies on CEPT, which use such type of polymers, need to assess the inhibitory and/or toxicity effect of the polymers on the downstream treatment processes.

CEPT sludge has good filterability and dewaterability compared to conventional primary treatment sludge, which will reduce the cost of drying or dewatering processes [20,86]. It should also be noted that the higher phosphate removal efficiency of CEPT results in a significant amount of phosphate in the sludge. Therefore, there is a need for a P recovery process that separates it from other waste 
components, so that it can be recycled as a fertilizer or an ingredient in other valuable phosphorus products [87].

COD and $\mathrm{P}$ fractions removed can be recovered from the CEPT sludge using different methods that include anaerobic digestion and incineration to recover energy from COD; and physical, thermal, chemical, and biological technologies to recover P $[14,79]$. These available technologies recover $\mathrm{P}$ from wet sludge or sludge ash through either accumulation, release, or extraction [88]. However, some studies pointed out that the current $\mathrm{P}$ recovery technologies implemented in pilot or large-scale applications that include wet-chemical extraction/leaching, wet-oxidation, precipitation, and thermochemical treatment are associated with comparatively high emissions and energy demand making it difficult to present an ideal recovery technology $[89,90]$.

\section{Comparison of CEPT with Other Alternative Methods}

As described in the introduction section, CEPT is a chemical process where chemicals are added for the up-concentration of organic matter. However, there are also other processes that could be employed for the up-concentration of organics and capturing them onto sludge. These processes can be considered as an alternative to CEPT and include (1) physical processes (dynamic sand filtration and membrane filtration), and (2) biological processes (adsorption/bio-oxidation process and contact stabilization) [91]. A detailed review of these alternative processes has previously been provided by Sancho et al. [91] and Guven et al. [92]. Guven et al. [92] discussed these processes and provided their strengths and constraints. Sancho et al. [91] suggested that a combination of both physical and biological separation processes is a promising process for carbon redirection.

Some studies proposed high-rate contact stabilization (HiCS) as a promising primary treatment technology with which to maximize the redirection of organics to sludge for subsequent energy recovery [93-95]. The HiCS utilizes a feast-famine cycle to select for bioflocculation, intracellular storage, or both. Return sludge is aerated in a stabilization phase (famine) before it is brought into contact with wastewater under anaerobic conditions (feast). Meerburg et al. [94] showed that HiCS, as a primary wastewater treatment technology, was able to recover up to $55 \%$ of incoming organic matter as sludge. Based on a pilot-scale study, Dolejs et al. [18] reported a COD removal of $76.6 \%$ using bioflocculation. Dolejs et al. [18] argue that bioflocculation-enhanced primary treatment has several benefits over CEPT or conventional primary treatment. In summary, a holistic assessment considering the advantages and disadvantages of these alternatives in comparison to CEPT should be made to decide the best method for the up-concentration of organic matter.

\section{Environmental Impacts}

Most CEPT studies focused on performance evaluation of CEPT and optimization of coagulants and flocculants dosages. These studies have based their criteria for optimization and selection on carbon, phosphorus, and suspended solids removal rates and far too little attention has been paid to the impact of CEPT on the environment. Achieving lower residual coagulant or flocculants concentration in the effluent and minimizing adverse effects in the downstream biological processes should be considered and evaluated in CEPT applications to avoid environmental impact. It should be noted that coagulant recovery processes might have the potential to reduce the environmental impacts of water and wastewater coagulation processes [96]. An alternative method where chemicals are not needed is using bio-flocculation and adsorption, as the sludge itself can be used as a flocculent to enhance the treatment results [97]. The additional cost of chemicals is eliminated, and at the same time, the impact of chemicals in downstream processes is avoided.

The development of a holistic approach for the environmental impact of CEPT is complex, and appropriate metrics such as footprint, required wastewater quality of the primary effluent, plant capacity, greenhouse emission, etc., should all simultaneously be considered [70]. The available assessment methods presented by Maktabifard et al. [5], could help in analyzing the impact of CEPT on the environment. These assessment methods include economic Efficiency analysis (EEA), 
carbon footprint analysis (CFA), life cycle analysis (LCA), data envelopment analysis (DEA), and plant-wide modeling.

\section{Conclusions}

CEPT is a successful and preeminent method for carbon redirection and nutrient removal and can be considered as a promising method to recover resources from wastewater. The overall cost-effectiveness and environmental impact of coagulants should be considered in the evaluation of coagulants. To satisfy many of the principles of sustainability, the recovery of carbon and phosphorus from the CEPT sludge and reuse of coagulants are essential. The limitation in CEPT application studies conducted so far lies in the fact that the environmental impact of coagulants and flocculants is not addressed. These chemicals used in CEPT may be toxic and affect the biodegradability of CEPT sludge and/or the performance of downstream biological treatment processes. Moreover, the characteristics of final effluent, which is discharged to receiving water bodies, may be affected. Therefore, coagulants and flocculants selection should also address the minimization of environmental impact. The use of natural coagulants and environmentally friendly flocculants are encouraged to avoid toxic effects and promote sustainability.

Supplementary Materials: The following are available online at http://www.mdpi.com/2071-1050/12/15/5928/s1, Figure S1: Attractive and repulsive forces that result when two particles are brought together, Table S1: Comparison of different polymers, Table S2: Alternative matrix of polymers using equilibrate weight distribution.

Author Contributions: W.A.S. conceived and prepared the draft manuscript, M.D. reviewed, edited, and contributed to the final paper. All authors have read and agreed to the published version of the manuscript.

Funding: This research received no external funding.

Conflicts of Interest: The authors declare no conflict of interest.

\section{References}

1. Tchobanoglous, G.; Stensel, H.D.; Tsuchihashi, R.; Burton, F.L. Wastewater Engineering: Treatment and Resource Recovery, 5th ed.; McGraw-Hill Education: New York, NY, USA, 2014.

2. Verma, A.K.; Dash, R.R.; Bhunia, P. A review on chemical coagulation/flocculation technologies for removal of colour from textile wastewaters. J. Environ. Manag. 2012, 93, 154-168. [CrossRef] [PubMed]

3. Bratby, J. Coagulation and Flocculation in Water and Wastewater Treatment, 3rd ed.; IWA Publishing: London, $\mathrm{UK}, 2016$.

4. Bachis, G.; Maruéjouls, T.; Tik, S.; Amerlinck, Y.; Melcer, H.; Nopens, I.; Lessard, P.; Vanrolleghem, P.A. Modelling and characterization of primary settlers in view of whole plant and resource recovery modelling. Water Sci. Technol. 2015, 12, 2251-2261. [CrossRef] [PubMed]

5. Maktabifard, M.; Zaborowska, E.; Makinia, J. Achieving energy neutrality in wastewater treatment plants through energy savings and enhancing renewable energy production. Rev. Environ. Sci. Biotechnol. 2018, 17, 655-689. [CrossRef]

6. Chua, S.C.; Chong, F.K.; Malek, M.A.; Mustafa, M.R.U.; Ismail, N.; Sujarwo, W.; Lim, J.W.; Ho, Y.C. Optimized use of ferric chloride and sesbania seed gum (SSG) as sustainable coagulant aid for turbidity reduction in drinking water treatment. Sustainability 2020, 12, 2273. [CrossRef]

7. Nath, A.; Mishra, A.; Pande, P.P. A review natural polymeric coagulants in wastewater treatment. Mater. Today Proc. 2020, in press. [CrossRef]

8. Neupane, D.R.; Riffat, R.; Murthy, S.N.; Peric, M.R.; Wilson, T.E. Influence of Source Characteristics, Chemicals, and Flocculation on Chemically Enhanced Primary Treatment. Water Environ. Res. 2008, 80, 331-338. [CrossRef]

9. Harleman, D.R.F.; Murcott, S. The role of physical-chemical wastewater treatment in the mega-cities of the developing world. Water Sci. Technol. 1999, 40, 75-80. [CrossRef]

10. Ju, F.; Wang, Y.; Lau, F.T.K.; Fung, W.C.; Huang, D.; Xia, Y.; Zhang, T. Anaerobic digestion of chemically enhanced primary treatment (CEPT) sludge and the microbial community structure. Appl. Microbiol. Biotechnol. 2016, 100, 8975-8982. [CrossRef] 
11. He, Q.; Wang, H.; Xu, C.; Zhang, J.; Zhang, W.; Zou, Z.; Yang, K. Feasibility and optimization of wastewater treatment by chemically enhanced primary treatment (CEPT): A case study of Huangshi. Chem. Speciat. Bioavailab. 2016, 28, 209-215. [CrossRef]

12. Wang, H.; Li, F.; Keller, A.A.; Xu, R. Chemically enhanced primary treatment (CEPT) for removal of carbon and nutrients from municipal wastewater treatment plants: A case study of Shanghai. Water Sci. Technol. 2009, 60, 1803-1809. [CrossRef]

13. Haydar, S.; Aziz, J.A. Characterization and treatability studies of tannery wastewater using chemically enhanced primary treatment (CEPT)-A case study of Saddiq Leather Works. J. Hazard. Mater. 2009, 163, 1076-1083. [CrossRef] [PubMed]

14. Shewa, W.A.; Dong, T.; Mu, W.; Murray, K.; Dagnew, M. The impact of chemically enhanced primary treatment on the downstream liquid and solid train processes. Water Environ. Res. 2019, 92, 359-368. [CrossRef] [PubMed]

15. Wan, J.; Gu, J.; Zhao, Q.; Liu, Y. COD capture: A feasible option towards energy self-sufficient domestic wastewater treatment. Sci. Rep. 2016, 6, 25054. [CrossRef] [PubMed]

16. Aiyuk, S.; Xu, H.; van Haandel, A.; Verstraete, W. Removal of ammonium nitrogen from pretreated domestic sewage using a natural ion exchanger. Environ. Technol. 2004, 25, 1321-1330. [CrossRef] [PubMed]

17. Mehrabi, S.; Houweling, D.; Dagnew, M. Establishing mainstream nitrite shunt process in membrane aerated biofilm reactors: Impact of organic carbon and biofilm scouring intensity. J. Water Process Eng. 2020, 37, 101460. [CrossRef]

18. Dolejš, P.; Varga, Z.; Luza, B.; Pícha, A.; Jeníček, P.; Jeison, D.; Bartáček, J. Maximizing energy recovery from wastewater via bioflocculation-enhanced primary treatment: A pilot scale study. Environ. Technol. 2019, 1-11. [CrossRef]

19. Nacheva, P.M.; Bustillos, L.T.; Camperos, E.R.; Armenta, S.L.; Vigueros, L.C. Characterization and coagulation-flocculation treatability of Mexico City wastewater applying ferric chloride and polymers. Water Sci. Technol. 1996, 34, 235-247. [CrossRef]

20. Poon, C.S.; Chu, C.W. The use of ferric chloride and anionic polymer in the Chemically Assisted Primary Sedimentation Process. Chemosphere 1999, 39, 1573-1582. [CrossRef]

21. Aiyuk, S.; Amoako, J.; Raskin, L.; Van Haandel, A.; Verstraete, W. Removal of carbon and nutrients from domestic wastewater using a low investment, integrated treatment concept. Water Res. 2004, 38, 3031-3042. [CrossRef]

22. Bhuptawat, H.; Folkard, G.K.; Chaudhari, S. Innovative physico-chemical treatment of wastewater incorporating Moringa oleifera seed coagulant. J. Hazard. Mater. 2007, 142, 477-482. [CrossRef]

23. Johnson, P.D.; Girinathannair, P.; Ohlinger, K.N.; Ritchie, S.; Teuber, L.; Kirby, J. Enhanced Removal of Heavy Metals in Primary Treatment Using Coagulation and Flocculation. Water Environ. Res. 2008, 80, 472-479. [CrossRef] [PubMed]

24. Mahmoued, E.K. Application of cement kiln dust for chemically enhanced primary treatment of municipal wastewater. Desalin. Water Treat. 2014, 52, 4698-4704. [CrossRef]

25. Lin, L.; Li, R.-H.; Li, X.-Y. Recovery of organic resources from sewage sludge of Al-enhanced primary sedimentation by alkali pretreatment and acidogenic fermentation. J. Clean. Prod. 2018, 172, 3334-3341. [CrossRef]

26. Dong, T.; Shewa, W.A.; Murray, K.; Dagnew, M. Optimizing chemically enhanced primary treatment processes for simultaneous carbon redirection and phosphorus removal. Water 2019, 11, 547. [CrossRef]

27. Yang, H.; Liu, J.; Hu, P.; Zou, L.; Li, Y.Y. Carbon source and phosphorus recovery from iron-enhanced primary sludge via anaerobic fermentation and sulfate reduction: Performance and future application. Bioresour. Technol. 2019, 294, 122174. [CrossRef]

28. Chakraborty, T.; Balusani, D.; Smith, S.; Santoro, D.; Walton, J.; Nakhla, G.; Ray, M.B. Reusability of recovered iron coagulant from primary municipal sludge and its impact on chemically enhanced primary treatment. Sep. Purif. Technol. 2020, 231, 115894. [CrossRef]

29. Lin, L.; Li, R.-H.; Li, Y.; Xu, J.; Li, X.-Y. Recovery of organic carbon and phosphorus from wastewater by Fe-enhanced primary sedimentation and sludge fermentation. Process Biochem. 2017, 54, 135-139. [CrossRef]

30. Tatsi, A.A.; Zouboulis, A.I.; Matis, K.A.; Samaras, P. Coagulation-flocculation pretreatment of sanitary landfill leachates. Chemosphere 2003, 53, 737-744. [CrossRef] 
31. Ghafari, S.; Aziz, H.A.; Isa, M.H.; Zinatizadeh, A.A. Application of response surface methodology (RSM) to optimize coagulation-flocculation treatment of leachate using poly-aluminum chloride (PAC) and alum. J. Hazard. Mater. 2009, 163, 650-656. [CrossRef]

32. Al-Hamadani, Y.A.J.; Yusoff, M.S.; Umar, M.; Bashir, M.J.K.; Adlan, M.N. Application of psyllium husk as coagulant and coagulant aid in semi-aerobic landfill leachate treatment. J. Hazard. Mater. 2011, 190, 582-587. [CrossRef]

33. Cheng, S.Y.; Show, P.L.; Juan, J.C.; Ling, T.C.; Lau, B.F.; Lai, S.H.; Ng, E.P. Sustainable landfill leachate treatment: Optimize use of guar gum as natural coagulant and floc characterization. Environ. Res. 2020, 188. [CrossRef]

34. Tawakkoly, B.; Alizadehdakhel, A.; Dorosti, F. Evaluation of COD and turbidity removal from compost leachate wastewater using Salvia hispanica as a natural coagulant. Ind. Crop. Prod. 2019, 137, 323-333. [CrossRef]

35. Chi, F.H.; Cheng, W.P. Use of chitosan as coagulant to treat wastewater from milk processing plant. J. Polym. Environ. 2006, 14, 411-417. [CrossRef]

36. Tran, N.V.N.; Yu, Q.J.; Nguyen, T.P.; Wang, S.L. Coagulation of chitin production wastewater from shrimp scraps with by-product chitosan and chemical coagulants. Polymers 2020, 12, 607. [CrossRef] [PubMed]

37. Amuda, O.S.; Amoo, I.A. Coagulation/flocculation process and sludge conditioning in beverage industrial wastewater treatment. J. Hazard. Mater. 2007, 141, 778-783. [CrossRef] [PubMed]

38. Ahmad, A.L.; Wong, S.S.; Teng, T.T.; Zuhairi, A. Improvement of alum and PACl coagulation by polyacrylamides (PAMs) for the treatment of pulp and paper mill wastewater. Chem. Eng. J. 2008, 137, 510-517. [CrossRef]

39. Wang, J.P.; Chen, Y.Z.; Wang, Y.; Yuan, S.J.; Yu, H.Q. Optimization of the coagulation-flocculation process for pulp mill wastewater treatment using a combination of uniform design and response surface methodology. Water Res. 2011, 45, 5633-5640. [CrossRef]

40. Asif, M.B.; Majeed, N.; Iftekhar, S.; Habib, R.; Fida, S.; Tabraiz, S. Chemically enhanced primary treatment of textile effluent using alum sludge and chitosan. Desalin. Water Treat. 2016, 57, 7280-7286. [CrossRef]

41. Dehghani, M.; Alizadeh, M.H. The effects of the natural coagulant Moringa oleifera and alum in wastewater treatment at the Bandar Abbas Oil Refinery. Environ. Heal. Eng. Manag. 2016, 3, 225-230. [CrossRef]

42. Huzir, N.M.; Aziz, M.M.A.; Ismail, S.B.; Mahmood, N.A.N.; Umor, N.A.; Faua'ad Syed Muhammad, S.A. Optimization of coagulation-flocculation process for the palm oil mill effluent treatment by using rice husk ash. Ind. Crop. Prod. 2019, 139, 111482. [CrossRef]

43. Gong, W.; Luo, L.; Li, W.; Luo, X.; Liang, H.; Ngo, H.H.; Guo, W. Using Chemically Enhanced Primary Treatment (CEPT) as a pretreatment option for anaerobic digestate from cattle manure digestion system. Water 2017, 9, 487. [CrossRef]

44. Xu, G.R.; Yan, Z.C.; Wang, Y.C.; Wang, N. Recycle of Alum recovered from water treatment sludge in chemically enhanced primary treatment. J. Hazard. Mater. 2009, 161, 663-669. [CrossRef]

45. Moosvi, S.; Madamwar, D. An integrated process for the treatment of CETP wastewater using coagulation, anaerobic and aerobic process. Bioresour. Technol. 2007, 98, 3384-3392. [CrossRef] [PubMed]

46. Riera-Torres, M.; Gutiérrez-Bouzán, C.; Crespi, M. Combination of coagulation-flocculation and nanofiltration techniques for dye removal and water reuse in textile effluents. Desalination 2010, 252, 53-59. [CrossRef]

47. Zhao, C.; Chen, W. A review for tannery wastewater treatment: Some thoughts under stricter discharge requirements. Environ. Sci. Pollut. Res. 2019, 26, 26102-26111. [CrossRef] [PubMed]

48. Asakura, H.; Matsuto, T. Experimental study of behavior of endocrine-disrupting chemicals in leachate treatment process and evaluation of removal efficiency. Waste Manag. 2009, 29, 1852-1859. [CrossRef]

49. Suarez, S.; Lema, J.M.; Omil, F. Pre-treatment of hospital wastewater by coagulation-flocculation and flotation. Bioresour. Technol. 2009, 100, 2138-2146. [CrossRef]

50. Zhou, G.J.; Lin, L.; Li, X.Y.; Leung, K.M.Y. Removal of emerging contaminants from wastewater during chemically enhanced primary sedimentation and acidogenic sludge fermentation. Water Res. 2020, 175, 115646. [CrossRef]

51. Taboada-Santos, A.; Rivadulla, E.; Paredes, L.; Carballa, M.; Romalde, J.; Lema, J.M. Comprehensive comparison of chemically enhanced primary treatment and high-rate activated sludge in novel wastewater treatment plant configurations. Water Res. 2020, 169, 115258. [CrossRef] 
52. Gregory, J. Particles in Water: Properties and Processes; CRC Press: Boca Raton, FL, USA, 2006.

53. Reynolds, T.D.; Richards, P.A. Unit Operations and Processes in Environmental Engineering, 2nd ed.; PWS Publishing Company: Boston, MA, USA, 1996.

54. Ghernaout, D.; Ghernaout, B. Sweep flocculation as a second form of charge neutralisation-A review. Desalin. Water Treat. 2012, 44, 15-28. [CrossRef]

55. Droste, R.L.; Gehr, R.L. Theory and Practice of Water and Wastewater Treatment, 2nd ed.; John Wiley and Sons, Inc.: Hoboken, NJ, USA, 2019.

56. Edzwald, J.K. Water Quality and Treatment: A Handbook on Drinking Water, 6th ed.; McGraw-Hill Education: New York, NY, USA, 2010.

57. Renault, F.; Sancey, B.; Badot, P.M.; Crini, G. Chitosan for coagulation/flocculation processes-An eco-friendly approach. Eur. Polym. J. 2009, 45, 1337-1348. [CrossRef]

58. De Feo, G.; De Gisi, S.; Galasso, M. Definition of a practical multi-criteria procedure for selecting the best coagulant in a chemically assisted primary sedimentation process for the treatment of urban wastewater. Desalination 2008, 230, 229-238. [CrossRef]

59. Hu, K.; Zhao, Q.L.; Chen, W.; Tang, F.; Xu, H. Preparation and performance of fly ash-based coagulants in chemically enhanced primary treatment of domestic wastewater. Desalin. Water Treat. 2016, 57, 4429-4438. [CrossRef]

60. Xu, G.R.; Yan, Z.C.; Wang, N.; Li, G.B. Ferric coagulant recovered from coagulation sludge and its recycle in chemically enhanced primary treatment. Water Sci. Technol. 2009, 60, 211-219. [CrossRef] [PubMed]

61. Taheriyoun, M.; Memaripour, A.; Nazari-Sharabian, M. Using recycled chemical sludge as a coagulant aid in chemical wastewater treatment in Mobarakeh Steel Complex. J. Mater. Cycles Waste Manag. 2020, 1-12. [CrossRef]

62. Filippou, D.; Hudon, G. Iron removal and recovery in the titanium dioxide feedstock and pigment industries. JOM 2009, 61, 36. [CrossRef]

63. Czerwionka, K.; Wilinska, A.; Tuszynska, A. The Use of Organic Coagulants in the Primary Precipitation Process at Wastewater Treatment Plants. Water 2020, 12, 1650. [CrossRef]

64. Luo, X.; Liang, C.; Hu, Y. Comparison of different enhanced coagulation methods for azo dye removal fromwastewater. Sustainability 2019, 11, 4760. [CrossRef]

65. Gautam, S.; Saini, G. Use of natural coagulants for industrial wastewater treatment. Glob. J. Environ. Sci. Manag. 2020, 6, 553-578. [CrossRef]

66. Ang, W.L.; Mohammad, A.W. State of the art and sustainability of natural coagulants in water and wastewater treatment. J. Clean. Prod. 2020, 262, 121267. [CrossRef]

67. Hatton, W.; Simpson, A.M. Use of alternative aluminium based chemicals in coagulation with particular reference to phosphorus removal. Environ. Technol. Lett. 1985, 6, 225-230. [CrossRef]

68. Gori, R.; Jiang, L.M.; Sobhani, R.; Rosso, D. Effects of soluble and particulate substrate on the carbon and energy footprint of wastewater treatment processes. Water Res. 2011, 45, 5858-5872. [CrossRef] [PubMed]

69. Diamantis, V.; Verstraete, W.; Eftaxias, A.; Bundervoet, B.; Vlaeminck, S.E.; Melidis, P.; Aivasidis, A. Sewage pre-concentration for maximum recovery and reuse at decentralized level. Water Sci. Technol. 2013, 67, 1188-1193. [CrossRef] [PubMed]

70. Lema, J.M.; Suarez, S. Innovative Wastewater Treatment \& Resource Recovery Technologies: Impacts on Energy, Economy and Environment. Water Intell. Online 2017. [CrossRef]

71. Jarvis, P.; Jefferson, B.; Parsons, S.A. Floc structural characteristics using conventional coagulation for a high doc, low alkalinity surface water source. Water Res. 2006, 40, 2727-2737. [CrossRef]

72. Murugesan, K.; Selvam, A.; Wong, J.W.C. Flocculation and dewaterability of chemically enhanced primary treatment sludge by bioaugmentation with filamentous fungi. Bioresour. Technol. 2014, 168, 198-203. [CrossRef]

73. Guibal, E.; Van Vooren, M.; Dempsey, B.A.; Roussy, J. A Review of the Use of Chitosan for the Removal of Particulate and Dissolved Contaminants. Sep. Sci. Technol. 2006, 41, 2487-2514. [CrossRef]

74. Popovic, O.; Gioelli, F.; Dinuccio, E.; Rollè, L.; Balsari, P. Centrifugation of digestate: The effect of chitosan on separation efficiency. Sustainability 2017, 9, 2302. [CrossRef] 
75. Pasztor, I.; Thury, P.; Pulai, J. Chemical oxygen demand fractions of municipal wastewater for modeling of wastewater treatment. Int. J. Environ. Sci. Technol. 2009, 6, 51-56. [CrossRef]

76. Melcer, H.; Dold, P.L.; Jones, R.M.; Bye, C.M.; Takacs, I.; Stensel, H.D.; Wilson, A.W.; Sun, P.; Bury, S. Methods for Wastewater Characterization in Activated Sludge Modelling; Water Environment Research Foundation (WERF): Alexandria, VA, USA, 2008.

77. APHA; AWWA; WPCF. Standard Methods for the Examination of Water and Wastewater, 23rd ed.; American Public Health Association: Washington, DC, USA, 2017.

78. Dynamita, SARL. Sumo19. Available online: http://www.dynamita.com (accessed on 6 January 2020).

79. Venkiteshwaran, K.; McNamara, P.J.; Mayer, B.K. Meta-analysis of non-reactive phosphorus in water, wastewater, and sludge, and strategies to convert it for enhanced phosphorus removal and recovery. Sci. Total Environ. 2018, 644, 661-674. [CrossRef]

80. Henze, M.; van Loosdrecht, M.C.M.; Ekama, G.A.; Brdjanovic, D. Biological Wastewater Treatment: Principles, Modelling and Design; IWA Publishing: London, UK, 2008.

81. Baalbaki, Z.; Torfs, E.; Maere, T.; Yargeau, V.; Vanrolleghem, P.A. Dynamic modelling of solids in a full-scale activated sludge plant preceded by CEPT as a preliminary step for micropollutant removal modelling. Bioprocess Biosyst. Eng. 2017. [CrossRef] [PubMed]

82. Ødegaard, H. Optimised particle separation in the primary step of wastewater treatment. Water Sci. Technol. 1998, 37, 45-53. [CrossRef]

83. Cano, R.; Pérez-Elvira, S.I.; Fdz-Polanco, F. Energy feasibility study of sludge pretreatments: A review. Appl. Energy 2015, 20, 53-60. [CrossRef]

84. Li, Y.-Y.; Lin, L.; Li, X.-Y. Chemically enhanced primary sedimentation and acidogenesis of organics in sludge for enhanced nitrogen removal in wastewater treatment. J. Clean. Prod. 2020, 244, 118705. [CrossRef]

85. Lin, L.; Li, R.-H.; Yang, Z.-Y.; Li, X.-Y. Effect of coagulant on acidogenic fermentation of sludge from enhanced primary sedimentation for resource recovery: Comparison between $\mathrm{FeCl}_{3}$ and $\mathrm{PACl}$. Chem. Eng. J. 2017, 325, 681-689. [CrossRef]

86. Kooijman, G.; De Kreuk, M.K.; Van Lier, J.B. Influence of chemically enhanced primary treatment on anaerobic digestion and dewaterability of waste sludge. Water Sci. Technol. 2017, 76, 1629-1639. [CrossRef]

87. De-Bashan, L.E.; Bashan, Y. Recent advances in removing phosphorus from wastewater and its future use as fertilizer (1997-2003). Water Res. 2004, 38, 4222-4246. [CrossRef]

88. Mehta, C.M.; Khunjar, W.O.; Nguyen, V.; Tait, S.; Batstone, D.J. Technologies to recover nutrients from waste streams: A critical review. Crit. Rev. Environ. Sci. Technol. 2015, 45, 385-427. [CrossRef]

89. Egle, L.; Rechberger, H.; Krampe, J.; Zessner, M. Phosphorus recovery from municipal wastewater: An integrated comparative technological, environmental and economic assessment of P recovery technologies. Sci. Total Environ. 2016, 571, 522-542. [CrossRef]

90. Amann, A.; Zoboli, O.; Krampe, J.; Rechberger, H.; Zessner, M.; Egle, L. Environmental impacts of phosphorus recovery from municipal wastewater. Resour. Conserv. Recycl. 2018, 130, 127-139. [CrossRef]

91. Sancho, I.; Lopez-Palau, S.; Arespacochaga, N.; Cortina, J.L. New concepts on carbon redirection in wastewater treatment plants: A review. Sci. Total Environ. 2019, 647, 1373-1384. [CrossRef] [PubMed]

92. Guven, H.; Dereli, R.K.; Ozgun, H.; Ersahin, M.E.; Ozturk, I. Towards sustainable and energy efficient municipal wastewater treatment by up-concentration of organics. Prog. Energy Combust. Sci. 2019, 70, 145-168. [CrossRef]

93. Meerburg, F.A.; Boon, N.; Van Winckel, T.; Vercamer, J.A.R.; Nopens, I.; Vlaeminck, S.E. Toward energy-neutral wastewater treatment: A high-rate contact stabilization process to maximally recover sewage organics. Bioresour. Technol. 2015, 179, 373-381. [CrossRef] [PubMed]

94. Meerburg, F.A.; Boon, N.; Van Winckel, T.; Pauwels, K.T.G.; Vlaeminck, S.E. Live fast, die young: Optimizing retention times in high-rate contact stabilization for maximal recovery of organics from wastewater. Environ. Sci. Technol. 2016, 50, 9781-9790. [CrossRef] [PubMed]

95. Rahman, A.; Meerburg, F.A.; Ravadagundhi, S.; Wett, B.; Jimenez, J.; Bott, C.; Al-Omari, A.; Riffat, R.; Murthy, S.; De Clippeleir, H. Bioflocculation management through high-rate contact-stabilization: A promising technology to recover organic carbon from low-strength wastewater. Water Res. 2016, 104, 485-496. [CrossRef] [PubMed] 
96. Keeley, J.; Jarvis, P.; Judd, S.J. Coagulant recovery from water treatment residuals: A review of applicable technologies. Crit. Rev. Environ. Sci. Technol. 2014, 44, 2675-2719. [CrossRef]

97. Zhao, W.; Ting, Y.P.; Chen, J.P.; Xing, C.H.; Shi, S.Q. Advanced primary treatment of waste water using a bio-flocculation-adsorption sedimentation process. Acta Biotechnol. 2000, 20, 53-60. [CrossRef]

(C) 2020 by the authors. Licensee MDPI, Basel, Switzerland. This article is an open access article distributed under the terms and conditions of the Creative Commons Attribution (CC BY) license (http://creativecommons.org/licenses/by/4.0/). 